\title{
Building The Case For Educating Business Leaders On The Importance Of Public Relations
}

Linda M. Hagan, Ph.D., Walsh College, USA

\begin{abstract}
An organization's well-developed strategic plan and reputation can crumble in minutes if it mishandles key communications, particularly during crises. Today's leaders need to appreciate the value of professional public relations and how it helps organizational effectiveness by building strategic relationships, maintaining a favorable reputation, minimizing damage from crisis, and generating revenue. Graduate business schools, educating future business leaders, need to include strategic communication and public relations as part of the required curriculum. This paper makes a case for educating business leaders on the importance of public relations as a critical management function.
\end{abstract}

Keywords: Public relations (PR); strategic communication; crisis management; reputation; business education; and leadership training

\section{INTRODUCTION}

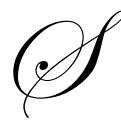

uccessful business executives need to know the tenets of professional public relations practice to lead their organizations in today's fast-paced, virtual, and global environment. Especially with the growth in new media and online social networking, the best-laid strategic plans can collapse if the onslaught of public opinion changes for the organization. As seen in recent years by organizations such as BP Oil, Goldman Sachs, and Toyota, an organization's future is altered and all areas of the business are affected when a crisis strikes, particularly if the organization mishandles its response to the crisis.

Most executives are caught off-guard and are ill prepared for handling crises. In many cases, many business leaders have had little training in the importance of message formulation and response strategies to communicate effectively to internal and external stakeholders, not only in bad times, but in good times as well. The relevance of public opinion and the power of the media, both traditional and new media, are overshadowed by strategies to grow the business, produce better profits, keep shareholders happy, and make more money. While business leaders may not manage the day-to-day operations of their organizations, they are responsible for the public relations responsibilities of building strategic relationships and managing their organization's reputation. Internal and external constituencies identify the organization by its senior leadership team, especially the CEO and others from the Csuite. Public relations is a critical management function because business leaders are the PR people for the organization. For this reason, teaching business leaders about strategic communications and public relations is critical, and it needs to start early in graduate business programs.

\section{WHAT IS PUBLIC RELATIONS?}

Very simply, public relations is developing and maintaining strategic relationships with the various publics of an organization. According to leading public relations scholar James E. Grunig and Todd Hunt (1984), the classic definition of public relations is "the management of communication between an organization and its publics" (p. 6). As defined by the Public Relations Society of America (PRSA), public relations is a management function that "helps an organization and its publics adapt mutually to each other" (PRSA, 2011, para. 2). "Publics" are the various 
stakeholders, strategic constituencies, or target groups of an organization including employees, customers, shareholders, community members, government, media, competitors, and, as sometimes referred to as the "general public." Different from the traditional communications and marketing term of target audiences, publics are not "audiences," which implies passive groups that an organization communicates following a one-way communication model. Instead, to public relations practitioners, stakeholders are aware or active (e.g., activists) publics that organizations (i.e., organizational leaders) need to develop and maintain mutually beneficial relationships with.

A study led by James Grunig, Larissa Grunig, and David Dozier, commissioned by the International Association of Business Communicators (IABC) of CEOs, public relations practitioners and employees at 300 organizations in the United States, Canada, and Great Britain, determined that excellent public relations is an empowered, strategic management function that emphasizes ethical, two-way symmetrical communication (L. Grunig et al., 2002). Excellent public relations adds value by improving organizational effectiveness while reducing costs and generating revenue for the organization.

The function of public relations includes the monitoring of public opinion via internal and external networks (traditional, new and social media), development of strategic communication strategies, formulation of targeted messages, and building and maintaining strategic relationships, while addressing the merits of ethics and social responsibility. Public relations is not propaganda, spin, or a marketing function (although PR too many times is subjugated under the marketing umbrella as free publicity or free advertising). Public relations includes media publicity and goodwill, but more importantly, public relations is relationship management, reputation management, issues management, and crisis management.

\section{Public relations is relationship management}

Public relations is the business of relationships. Cutlip, Center, and Broom (2000) defined public relations as "the management function that establishes and maintains mutually beneficial relationships between an organization and its publics on whom its success or failure depend" (p. 6). Broom, Casey and Ritchey (1997) defined relationships in public relations as "dynamic results of the exchanges and reciprocity that manifest themselves as the relationships develop and evolve" (p. 95). Recent studies of public relations have focused on organization-public relationships (OPR). J. Grunig and Huang (2000) found that OPR is the function whereby organizations and publics trust each other, share influence, and are satisfied and committed to the relationship. Studies have identified types of relationships as exchange or communal (although in business practice sometimes the lines between customers, employees, and shareholders are blurred) and the characteristics of healthy relationships, which depend on trust and open communication. Studies have found a direct link between quality strategic relationships and positive organizational reputation. Healthy relationships, chiefly with customers and shareholders, along with good corporate reputation equate to profit generation.

\section{Public relations is reputation management}

Public relations can improve relationships with constituents and improve an organizations reputation. As such, business leaders need to learn to work with the external constituencies, especially traditional and new media, during good times and in crisis. Business leaders need to be aware of the differences between image, perception, and reputation. Historically, the practice of public relations was first rooted in propaganda campaigns with characters such as P.T. Barnum and his circus stunts. At the start of the $20^{\text {th }}$ century, business and government leaders began hiring in-house journalists and communications experts to help frame and effectively communicate their messages. Later, Edward L. Bernays, the "father of modern day public relations" and a nephew of Sigmund Freud, developed public relations into a profession of providing counsel to CEOs and organizations on communications strategies. Today, the practice of public relations focuses heavily on reputation management, maintaining an organization's reputation and attempting to restore reputations, in an ethical and socially responsible manner.

Public relations is the study of how public opinion is shaped and influenced by mediated adaptations of realities (e.g., the "power" of traditional, new and social media). Findings from a study on public relations, relationships, reputation, and crisis management, Hagan (2003) found that reputation "can be determined by what constituents think of the company based on its actual performance and first-hand experiences with it, as well as the 
constituent's perceptions of the company influenced by what they have read or heard from mediated channels," (p. 254).

\section{Public relations is issues management}

Public relations is oftentimes referred to as the eyes and ears for the organization in that it monitors issues and detects potential problems for the organization. Issues management is not crisis management or emergency preparedness, rather it is the process "which enables organizations to know, understand, and more effectively interact with their environments" (Dolphin, 1999, p. 207). Issues management is the proactive process of monitoring and assessing the emerging concerns, trends, cycles, societal challenges, and changes that can influence and alter the actions of the organization both positively and negatively. By environmental scanning, issues can be identified before they become problems. Issues management reduces risks and creates opportunities for the organization. Issues management allows leaders to act in a socially responsible manner and to properly formulate strategies and messages.

\section{Public relations is crisis communication}

According to the Institute of Crisis Management (2008), the majority of organizational crises are not due to economics, natural disasters, or terrorism, but "smoldering crisis" where management knows about problems, or should, before they blow up. Most business crises that get publicity are the results of management decisions/actions, or inactions. Additionally, the Internet has spawned social and consumer activism because it is easier for people to voice problems and complaints and mobilize quickly. Although the best way to manage crisis is to prevent it, crises will happen. From a PR perspective, how an organization reacts to the crisis affects how quickly, if at all, the organization recovers. It is not necessarily what an organization does, but how publics perceive the organization because perception is reality, especially in times of crisis. Leaders need to learn that the court of public opinion can be far more damning to an organization than the court of law. Principles of public relations can teach business leaders various response strategies (Schenkler \& Herrling, 2004) to mitigate the damage to the organization in the long term. Public relations can reduce potential costs incurred during crises by resolving conflicts and managing communication effectively before, during and after crises. There is evidence that "indicates that organizations that scan the environment for potential problem areas and maintain positive relationships with the organization's various publics handle and survive crises better than do others," (Hagan, 2007, p. 437).

\section{A HOLE IN BUSINESS SCHOOL CURRICULUM}

Successful and well-informed business leaders need acumen of the principles of accounting, finance, economics, marketing, product development, operations management, and business law, along with an understanding of management theories and best practices. However, there needs to be a transformation in the skills taught in business schools (Horwitz, 2011).

In a review of the curricula of top business programs (i.e., based on the 2010 rankings of MBA programs by BusinessWeek and U.S. News and World Report) there appears to be a growing movement to integrate "softskills" into business school curriculum with courses in business/management communication now part of the required curriculum. Typical of many B-schools, at a Michigan-based private business school, the core competencies expected of students earning a graduate business degree include a mastery of business discipline, and critical thinking, problem solving, and communication skills. Although good writing and verbal communication skills are critical, MBA students should be required to learn about public relations, including social media and crisis communications. However, the majority of graduate business programs tend to offer PR related courses as an elective, and predominantly as part of the marketing discipline.

Deborah Barrett (2008) in a book titled, Leadership Communication, outlined the framework for leadership communication, which included core skills, managerial skills, and corporate communication skills. According to Barrett (2008), core skills include written, oral, and visual communication abilities along with audience analysis and strategy. Managerial skills include personal ethos, emotional intelligence and cultural literacy, all of which are required to manage and work effectively with individuals and groups. Corporate communication skills (much like 
PR skills) enable leaders to become the "company's face and voice" (Barrett, 2008, p. 7) to the broader corporate community, while they communicate the organization's vision, manage corporate image, and deal with crisis communication situations.

\section{MAKING THE CASE FOR EDUCATING BUSINESS LEADERS}

Unfortunately, since few business schools have courses in public relations as part of the curriculum, typically business leaders learn about public relations by trial and error, much to the detriment of their organizations. In the majority of cases, business leaders realize the value of public relations after the fact, such as when an organization comes under media attention because of a crisis. When faced with a crisis, leaders are forced to react rather than lead.

As the face and voice of their organizations, senior management needs to be better prepared and more knowledgeable of the PR function. Companies should use public relations not only as a marketing tool, but should place value on its importance, similar to that of legal counsel. Companies must place greater emphasis on monitoring and scanning the company's external environment, and business leaders need to learn to adjust their practice to these changing demands.

In 2010, the Public Relations Society of America launched an initiative titled, "The Business Case for Public Relations," to inform CEOs and senior management of the value of public relations. According to Anthony D'Angelo, the co-chairman of the Public Relations Society of America's MBA/Business School Initiative, MBA programs are weak in teaching strategic communications/reputation management. According to D'Angelo, "Getting bad press is not the problem; all large entities experience some. What is at risk from this deficiency in graduate business education is company reputation, stock price, product sales and various executive jobs," (D'Angelo, 2010, para. 3). He noted, "But even communications-savvy CEOs are less astute about strategic communications" than about other roles; thus, "Business schools should take more responsibility in providing this vital leadership component," (D’Angelo, 2010, para. 8-9).

\section{PR LEARNING ACTIVITIES}

Following are some examples of learning activities for leadership training. [These examples are based on the author's experiences teaching graduate business communication courses, one of which is a required course for a cohort of students enrolled in a doctor of management program in executive leadership.]

\section{Participant Observation of New and Social Media}

Students learn about communicating with internal and external stakeholders through various direct and mediated channels. As part of the exercise, during an established period, students actively participate in social media through Facebook, Twitter, and LinkedIn, not just from a social networking vantage, but also from an issues monitoring standpoint. In addition, students "cyber surf" and review organizational websites, online newsrooms, chat rooms, and business blogs, especially those authored by corporate leaders.

\section{Mock Media Conferences}

Students are given the task of crafting a visionary statement and addressing organizational change. Students play the role of organizational leader during a mock media conference. Students prepare statements, key talking points, and responses to anticipated questions for the Q\&A portion of the press conference. During the exercise, students (assuming the role of a CEO) present opening remarks to the media and then field questions from the audience. Students learn how to react to "trick" questions sometimes posed by media and the dangers of saying "no comment" or agreeing to "off-the-record" interviews (Schenkler \& Herrling, 2004). Further, students also assume the role of the media, taking on reporter roles from mainstream and business print, online, and broadcast media, as well as popular independent blogs. Students read stories and watch/listen to news broadcasts and press conferences in preparation for their role as journalists. Based on their media role, students then develop probing and hard-hitting questions to ask their classmates during the news conference. Press conferences are videotaped and peer reviewed 
for appropriate delivery style and quality of content, and how well the leaders handle the pressure and stay on message.

3. Crisis Simulations and Role Playing

Many business educators (e.g., Budden \& Budden, 2011) utilize simulations to teach business students about crisis management situations. Students role-play an organizational scenario. As one example, students are randomly assigned corporate leadership roles such as chief executive officer, general counsel, chief financial officer, chief information officer, executive director of marketing, vice president of manufacturing, and director of human resources. During the simulation, students begin in a standard weekly meeting, when they receive word that an unexpected event has happened. Most typically, the students engage in a long and spirited discussion about how to handle the organization's response. However, the professor interrupts their meeting and informs them that the media, activist groups, governmental agencies, union groups, customers, and employees have begun to mobilize internationally via social media, engulfing the organization into a full-blown crisis within minutes. After which, students debate the proper response and learn how avoiding questions allows room for outsiders to interpret events that can be damaging to the organization's operations and reputation. The students gain awareness for the saying that "perception is reality."

4. Case Analysis and Lessons Learned

Textbooks, articles, and daily news stories are filled with real situations across industries of good practices and PR blunders. Organizational leaders and students can garner practical knowledge about public relations and the ethical, legal, financial, and social impact through examination of cases and discussion of the "lessons learned" from other organizations. One does not need to look too far to analyze how BP Oil, Toyota, Tiger Woods, Sony PlayStation, Charlie Sheen, and the U.S. and Japanese governments handled crises. The Public Relations Society of America website includes examples of cases studies that business students and leaders can learn about the importance public relations.

\section{CONCLUSION}

Today's leaders need to appreciate the value of professional public relations and how it adds to organizational effectiveness by building strategic relationships, maintaining a favorable reputation, minimizing damage from crisis, and generating revenue. When organizational leaders embrace professional public relations and communication practices, then leaders can positively influence organizational behavior and crisis management. Awareness for the importance of strategic communications with internal and external stakeholders is essential for all functional leadership roles. Graduate business schools, educating future business leaders, need to include strategic communication and public relations as part of the required curriculum. Experiential activities can help business students and leaders alike learn how to anticipate the unexpected.

\section{AUTHOR INFORMATION}

Linda M. Hagan, Ph.D., is Director of the Doctor of Management in Executive Leadership program at Walsh College, in Troy, Michigan. She teaches courses in leadership and strategic communication. She has taught at Michigan State University, Syracuse University, and the University of Maryland. Prior to academia, Dr. Hagan worked in corporate communications in the automotive industry. She is Accredited in Public Relations (APR) and an active member of the Public Relations Society of America Detroit Chapter. She earned her Ph.D. from the University of Maryland, a master's degree from the University of Arizona, and a B.B.A. from Eastern Michigan University. E-mail: lhagan@walshcollege.edu

\section{REFERENCES}

1. Barrett, D. J. (2008). Leadership communication. (2 $2^{\text {nd }}$ ed.). New York, NY: McGraw-Hill/Irwin.

2. Broom, G. M., Casey, S., \& Ritchey, J. (1997). Toward a concept and theory of organization-public relationships. Journal of Public Relations Research, 9, 83-98. 
3. Budden, C. B., \& Budden, M. C. (2011). Developing crisis management skills through a realistic case scenario. Paper presented at the Clute Institute 2011 New Orleans International Academic Conference, New Orleans, LA.

4. Cutlip, S. M., Center, A. H., \& Broom, G. M. (2000). Effective public relations (8th ed.). Upper Saddle River, NJ: Prentice-Hall.

5. D'Angelo, A. W. (2011, March 21). A telling omission in the MBA curriculum. The Financial Times. Retrieved from http://www.ft.com

6. Dolphin, R. (1999). The fundamentals of corporate communications. Woburn, MA: ButterworthHeinemann.

7. Grunig, L. A., Grunig, J. E., \& Dozier, D. M. (2002). Excellent public relations and effective organizations. Mahwah, NJ: Lawrence Erlbaum Associates.

8. Grunig, J. E., \& Huang, Y. (2000). From organizational effectiveness to relationship indicators: Antecedents of relationships, public relations strategies, and relationship outcomes. In J. A. Ledingham \& S. D. Bruning (Eds.), Public relations as relationship management: A relational approach to the study and practice of public relations (pp. 23-53). Mahwah, NJ: Lawrence Erlbaum Associates.

9. Grunig, J. E., \& Hunt, T. (1984). Managing public relations. New York: Holt, Rinehart \& Winston.

10. Hagan, L. M. (2007). For reputation's sake: Managing crisis communication. In E. L. Toth (Ed.), The Future of Excellence in Public Relations and Communication Management: Challenges for the Next Generation. Mahwah, NJ: Lawrence Erlbaum Associates.

11. Hagan, L. M. (2003). Public Relations, Relationships, and Reputation: A Case Study of a Safety Recall in the U.S. Automotive Industry. (Doctoral dissertation, The University of Maryland, College Park, 2003). Dissertation Abstracts International, 64. (06A). (UMI No. 3094492)

12. Institute for Crisis Management. (2008). Myths in Business Crisis Management. Retrieved from http://www.crisis experts.com.

13. Horwitz, F. (2010, May/June). Transforming the business school. BizEd, 34-39. Retrieved from http://www.aacsb.edu/publications

14. Public Relations Society of America. (2011). Public relations defined. The Public Relations Society of America.. Retrieved from: http://www.prsa.org/AboutPRSA/PublicRelationsDefined/

15. Schenkler, S., \& Herrling, T. (2004). Guide to media relations. Upper Saddle River, NJ: Pearson Education. 